\title{
THE AWAKENING OF INVESTMENT CREATION: A CASE STUDY FROM SOUTH-EAST ASIA
}

\author{
Kebangkitan Investment Creation: Studi Kasus dari Asia Tenggara \\ Indriana Oktavia, Kiki Verico \\ Magister of Economic Planning and Development Policy, University of Indonesia, \\ JI. Salemba Raya No.4, Central Jakarta, 10430, DKI Jakarta, Indonesia \\ Email: indrianaoktavia@gmail.com
}

Naskah diterima: 14/01/2020; Naskah direvisi: 13/05/2020; Disetujui diterbitkan: 01/09/2020;

Dipublikasikan online: 18/12/2020

\begin{abstract}
Abstrak
ASEAN membentuk integrasi ekonomi, seperti ASEAN Free Trade Area (AFTA), AFTA+1, dan ASEAN Economic Community (AEC), untuk meningkatkan perdagangan intra dan investasi antarnegara ASEAN. Tujuan dari penelitian ini adalah untuk meneliti dampak integrasi ekonomi ASEAN terhadap ASEAN FDI (AFDI) dan perdagangan intra ASEAN (AIT). Penelitian ini menggunakan data sepuluh negara ASEAN dan enam negara mitra selama periode 2001-2017 dan di estimasi dengan menggunakan Generalized Least-Square (GLS). Hasil estimasi menunjukkan CEPT-AFTA ASEAN6 tidak dapat meningkatkan AIT dan AFDI. Dampak positif CEPT-AFTA pada AFDI dan AIT hanya terjadi pada tahun 2015, meskipun dampak pada AIT tidak signifikan. Penelitian ini mengindikasikan bahwa AFTA+ dapat meningkatkan AIT dan AFDI antara negara-negara ASEAN+6. AEC memiliki dampak positif pada AFDI dan dampak negatif pada AIT. Penelitian ini juga menyimpulkan bahwa jika dengan kerangka ASEAN+ menyebabkan investment creation di kawasan ASEAN+6. Untuk memperkuat perdagangan dan investasi, maka pemerintah perlu memperkuat kerja sama melalui Regional Comprehensive Economic Partnership (RCEP).
\end{abstract}

Kata Kunci: ASEAN, FDI, AFTA, Perdagangan Intra, AEC

\begin{abstract}
ASEAN created several economic integrations, such as the ASEAN Free Trade Area (AFTA), AFTA+1, and ASEAN Economic Community (AEC), to increase intra-trade and investment between ASEAN countries. This study aimed to examine the impact of ASEAN economic integration to ASEAN FDI (AFDI) and ASEAN Intra-Trade (AIT). The data consists of ten ASEAN countries and six partner countries from 2001 to 2017. It was estimated using the Generalized Least-Square (GLS). Estimation results showed that CEPT-AFTA ASEAN6 could not increase AIT and AFDI. The positive impact of CEPT-AFTA on AFDI and AIT occurred in 2015, with insignificance on AIT. The study also indicated that AFTA+ could increase AIT and AFDI between ASEAN+6 countries. Contrarily, AEC provided a positive impact on AFDI and an insignificant negative impact on AIT. The study concluded that the ASEAN+ framework causes investment creation in ASEAN and partner countries. The government needs to strengthen cooperation through Regional Comprehensive Economic Partnership (RCEP) to escalate FDI and trade.
\end{abstract}

Keywords: ASEAN, FDI, AFTA, Intra-Trade, AEC

JEL Classification: F13, F14, F15

\section{INTRODUCTION}

In 1967, ASEAN was created to maintain regional peace and stability.
However, rapid external changes, such as rapid technological changes and the rise of global competitiveness and 
ASEAN economic growth in the last ten years, took place not as previously expected. As a consequence, ASEAN countries were left behind. At the $4^{\text {th }}$ ASEAN Summit in 1993, the first phase of economic integration in ASEAN was developed with the enactment of the ASEAN Free Trade Area (AFTA). AFTA was established to accelerate development by increasing trade and investment within ASEAN member countries (ASEAN, 2012). Countries that promote greater freedom of economic activities benefit more from FDI, and FTA is the way to increase the economic freedom (Zghidi, Mohamed Sghaier, \& Abida, 2016). The Common Effective Preferential Tariff (CEPT) is the primary mechanism for implementing AFTA in which the tariffs of traded goods will be gradually reduced in 15 years. In 2001, ASEAN6 (Indonesia, Malaysia, Thailand, Philippines, Singapore, and Brunei Darussalam) countries had succeeded in reducing tariffs by more than $90 \%$. In 2010, it was targeted that ASEAN6 set 0\% tariffs, and in 2015 it applied to ASEAN4 (Cambodia, Lao PDR, Myanmar, and Vietnam).

To face challenges across regional and global economics, ASEAN has been preparing long-term plans, including the ASEAN Economic Community (AEC) (Bank Indonesia, 2008). The AEC's primary purpose is to increase trade and investment flows and create a single market and production base (ASEAN, 2007). With the AEC in place, free flows of goods, services, investment, skilled labor, and capital flows are imposed. At the 12th ASEAN Summit in 2007 in Cebu, the ASEAN Blueprint, containing the AEC targets and schedules to accelerate the formation of the AEC, was enacted earlier to enforce in 2020. Before enacting AEC in 2015, ASEAN, which implemented an open regionalism system (Verico, 2017), has strengthened its competitiveness and increased trade and investment in the globalization era by having a Free Trade Agreement (FTA) with trade partner countries. ASEAN+ FTA is carried out with six partner countries, namely China, India, Japan, Korea, Australia, and New Zealand, and in the face of world protection, ASEAN+6 is trying to form RCEP for the sake of sustainability (Urata, 2018).

Following the ASEAN Economic Integrations, the increase of trade and investment turned out not according to the plan. Graph 1 showed that after the enactment of CEPT-AFTA for ASEAN6 


$$
\begin{array}{llllllllllllll}
24,38 & 24,92 & 25,15 & 24,98 & 24,82 & 24,51 & 25,13 & 24,31 & 24,42 & 24,39 & 23,99 & 23,56 & 23,08 & 22,91
\end{array}
$$
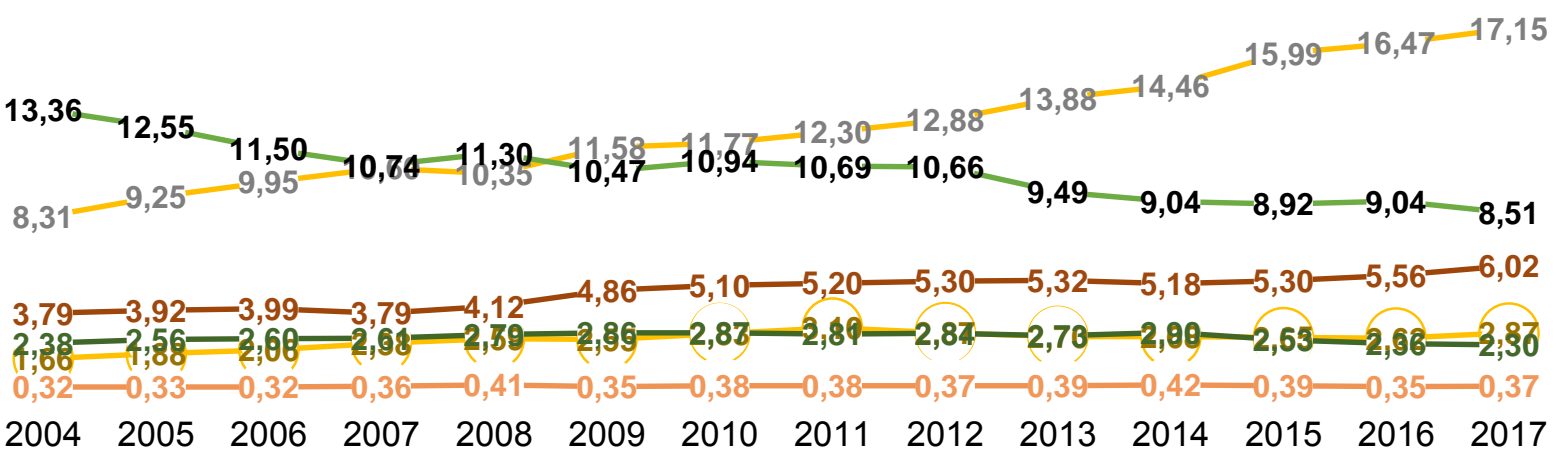

- -ASEAN - - China - - Jepang - - Korea Selatan $\frown$ India - -Australia - - New Zealand

\section{Graph 1.The Chart of ASEAN Trade Ratios with ASEAN and ASEAN+ Countries,}

\section{4-2017}

Source: ASEANStats Data Portal (2019)

in 2009, the ASEAN intra-trade ratio only increased in 2010 and continued to decline in the following years. Even after the enactment of CEPT-AFTA in four other ASEAN countries in 2015, the ASEAN intra-trade ratio did not increase. The total value even showed that exports have increased, but the ratio has continued to decline. In other words, without free trade agreements, trades between ASEAN countries and other countries are more significant. While intra-ASEAN trade continues to increase in line with the increase in exports (Basri, 2010), AEC, which was made effective at the end of 2015, has failed to encourage ASEAN intra-trade.
The impacts of ASEAN free trade are varied among countries. The implementation of FTA in Japan in 2008 showed a negative trend for ASEAN trade to Japan, and only the ratio of ASEAN trade with China increased. Even before the free trade agreement, the trend of ASEAN trade to China was already positive. Meanwhile, the impact of free trade cooperations with South Korea, India, Australia, and New Zealand toward ASEAN trade did not show a significant change.

Based on Graph 2, after the enactment of CEPT-AFTA for ASEAN6, ASEAN FDI declined in 2010 but was then followed by an increasing trend in 


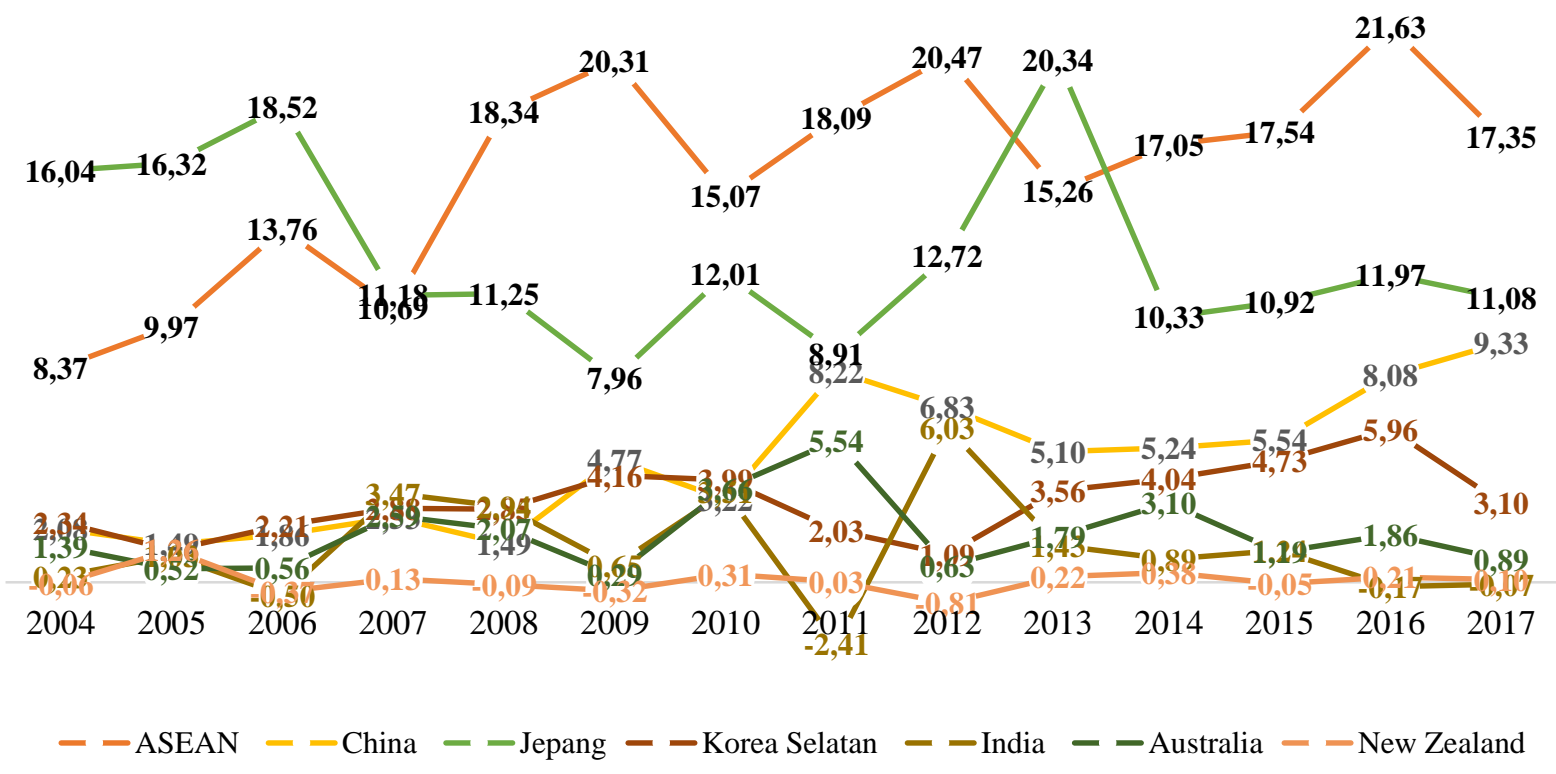

\section{Graph 2. Chart of ASEAN FDI Inflow Ratio with ASEAN and ASEAN+ Countries, 2004-2017}

Source: ASEANStats Data Portal (2019)

the following years. However, Masron \& Yusop (2012) discovered that CEPT or FTA did not significantly impact Foreign Direct Investment (FDI). The reason was that CEPT was not yet implemented for all ASEAN countries. On the contrary, Thangavelu \& Narjoko (2014) found that AFTA hurt FDI, indicating that there were restrictions in ASEAN countries, especially in the manufacturing sector and services such as transportation, communication, and aviation. Another indication showed that AFTA might positively impact FDI, but the capacity for domestic absorption of multinational companies must be included in the government's policy agenda. ASEAN must invest in physical infrastructure and improve the quality of human resources. It is supported by Ismail, Smith, \& Kugler (2009), who found that the enactment of AFTA contributed to the increase of FDI and trade. The study's limitation is that AFTA was observed based on the value of existing FDI, not on changes before and after the enactment of AFTA.

Following the CEPT-AFTA and AEC's enactment in 2015, the trend tends to increase, and it can be considered potential trade creation. According to Verico \& Natanael (2018), 
AFTA is proven to increase ASEAN FDI and significantly reduce intra-trade. AFTA positively and significantly give trade creation effects in a wide range of products for both imports and exports (Okabe \& Urata, 2014). It confirms the assumption that if AFTA is succeeded in increasing trade creation, the impact of $A E C$ will not be much different from AFTA, in which investment is increasing to compete with the domestic market and investors (Soekro, 2015).

The impact of the free trade agreement between ASEAN and Japan in 2008 on FDI inflow to ASEAN countries showed an increasing trend. It indicates a trade creation to ASEAN or FDI anti-trade (FDI that does not create trade and its products compete with local products). Following Japan, ASEAN enacted AFTA+ in 2010 with five other countries, China (ACFTA), South Korea (AKFTA), Australia \& New Zealand (AANZFTA), and India (AIFTA). AFTA+1 succeeds in reducing tariffs by up to $90 \%$ and opening investment opportunities from partner countries. However, only ACFTA and AKFTA showed a positive trend for trade ratio and FDI after the enactment. Li, Scollay, \& Maani (2016) confirmed that ACFTA had a positive impact on bilateral intratrade and FDI. The trade creation effects of ACFTA are higher than its trade diversion effects, suggesting that the investment creation effects will be more prominent than its investment diversion effects (Yang \& Martinez-Zarzoso, 2014).

In comparison, AANZFTA and AIFTA did not provide a significant change in investment inflows from Australia, New Zealand, and India following the enactment of AFTA+ in 2010. Nevertheless, the presence of $A S E A N+3$ is more effective in increasing intra-trade by up to $53 \%$. In line with the ASEAN's goal to build a production network in ASEAN, $A S E A N+3$ is more effective in increasing trade and investment (Magasházi, 2015).

This condition raised a question of whether ASEAN economic integration is needed to increase investment and trade between countries for strengthening economic scale and competitiveness. If the trade and investment continue to grow without economic integration, then economic integration is not needed by ASEAN countries. However, following the $35^{\text {th }}$ ASEAN Summit in Bangkok, ASEAN, with its five bilateral FTA partner countries, agreed to form a Regional Comprehensive Economic Partnership 
(RCEP) in 2020 (ASEAN, 2019). For this reason, the study has two objectives. First, to examine the impact of economic integration (CEPT-AFTA, AFTA+, and AEC) on ASEAN FDI and ASEAN IntraTrade. Second, to examine whether ASEAN economic integration is needed to increase intra-trade and FDI. This regional-level research is focused on ASEAN +6 countries (ASEAN, Australia, New Zealand, India, China, Japan, South Korea). This research is expected to observe the impact of ASEAN economic integration on intra-trade and ASEAN FDI in ASEAN+6 countries and determine the policies that ASEAN+6 countries should implement to increase ASEAN FDI and encourage trade. This research will be divided into four parts: introduction, research methods, results and discussion, conclusions and policy recommendations.

\section{RESEARCH METHODS}

ASEAN Intra-trade and FDI are not only influenced by economic integration but also by other determinants. It is generally believed that trade and FDI are affected by output (GDP), inflation, transaction costs, and several other factors. This section will analyze the determining factors of the increase in trade and investment.

\section{Determinants of Trade and FDI}

The shift in FDI trends to Asia is due to the relatively low wage rates and infrastructure improvements by Asian countries, which have attracted investors (Sethi, Guisinger, Phelan, \& Berg, 2003). In East and Southeast Asia, besides to wage levels, real GDP, and economic openness attract investors to invest in FDI (Hsiao \& Hsiao, 2004). Meanwhile, in a more recent study, Hsiao \& Hsiao (2006) found that inward FDI and GDP affected export. However, GDP and exports are not included as influencing factors that attract FDI inflows to eight Asian countries since no causality has been found between FDI and trade (Belloumi, 2014). Another study has found only one direction long-run causality export to FDI and unidirectional long-run causality FDI to Export in Europe and Asia (Mahmoodi \& Mahmoodi, 2016).

FDI inflow to ASEAN is influenced by investor's motives to open new markets and look for efficiency. Trade openness has a positive impact on FDI inflows, while higher labor costs decreased FDI inflows (Masron \& Nor, 2013). Besides labor cost and trade, exchange rate, and GDP also affect FDI (Aziz, 2018). Depreciation or devaluation of the host country's 
exchange rate and low inflation rate stimulated FDI inflow (Ismail, 2009). The enactment of FTA, the issuance of regulation according to UK provisions, and the quality of good governance will increase FDI inflow. Another factor, real GDP, had a significant and positive effect on FDI, which indicated a horizontal FDI (Hattari \& Rajan, 2009). Contrarily, the result of another study showed that vertical FDI and exportplatform are more dominant in ASEAN (Hoang \& Goujon, 2018). The other determinants of intra and extra FDI are infrastructure, trade costs, and political stability.

Another study found if there are different factors to attract more FDI for ASEAN countries, the government of CLMV countries should maintain investment stability with a low inflation rate, invest in infrastructure, and open itself to international trade. Nevertheless, those conditions do not happen for ASEAN5; with a higher inflation rate and a lower degree of openness, the foreign investors are still interested in investing more in this region. Cause the attractive factors of ASEAN5 are their market size and infrastructure facilities (Xaypanya, Rangkakulnuwat, \& Paweenawat, 2015). Trade liberalization that ASEAN countries do did not encourage export growth. Another policy implementation is needed, such as infrastructure improvements, the right business environment, and stable government policies to fit trade liberalization (Hadili, Raab, \& Wenzelburger, 2020).

Political instability depresses FDI inflows as it can lead to economic instability (Quazi, 2007). Thus, the government should issue trade policies that will attract investors (Shahzad, Mithani, Al-Swidi, \& Fadzil, 2012). Higher trade costs, bureaucracy complexity, and high tariffs will hamper FDI inflow, along with high wages and inflation (Cantah, Brafu-Insaidoo, Wiafe, \& Adams, 2018). At the same time, FDI from non-ASEAN countries is the other significant factor that affects intra-FDI. It is based on the belief that MNCs from developed countries or other countries can increase local entrepreneurs' competitiveness through technology transfer (Masron, 2013; Masron \& Yusop, 2012).

In another study, there is a two-way causality relationship between FDI and exports. Furthermore, open and exportoriented policies and higher domestic savings can boost trade (Majeed \& Ahmad, 2007). For some countries, FDI and exports can complement each 
other. Although in the aggregate, FDI and exports become substitutes for several host countries. Besides, economic growth leads to an improvement in terms of trade. Foreign Direct Investment (FDI) can provide a pathway for countries to enhance economic growth by increasing overall export productivity. So, there is the possibility of indirect causality between trade and FDI (Jawaid, Raza, Mustafa, \& Karim, 2016).

Exports are also influenced by inflation, in which the increase in the inflation rate exerts a significant and negative influence over the rate of exports (Tran, Alauddin, \& Tran, 2019). This study also found that trade openness encouraged export rate, thereby confirming the findings $(\mathrm{Ju}, \mathrm{Wu}$, \& Zeng, 2010). Communication facilities such as internet services encourage FDI inflow and promote exports (Choi, 2003; Lin, 2015). It can be concluded, besides economic integration, determinants of FDI and intra-trade are market size, economic openness, wages, political stability, exchange rates, inflation, infrastructure, and savings.

\section{Methodology}

The model in this research is developed based on Hsiao \& Hsiao (2006). ASEAN+6 FDI and intra-trade are dependent variables. The independent variables include ASEAN economic integration dummy variables, market size, trade openness, infrastructure, real wages, inflation, exchange rates, saving, and FDI from non-member countries. All independent variables were drawn based on previous studies. The models used in this study are as follows:

$A I T_{i t}=\alpha_{1 i}+\beta_{1} A F D I_{i t}+\beta_{2} D O O_{i t}+$ $\beta_{3} G D P_{i t-1}+\beta_{4} I U_{i t}+\beta_{5} R W_{i t}+$ $\beta_{6} I N F_{i t}+\beta_{7} E R_{i t}+\beta_{8} S A V_{i t}+$ $\beta_{9} C E P T 1_{i t}+\beta_{10} C E P T 2_{i t}+$ $\beta_{11}$ AJFTA $_{i t}+\beta_{12}$ ASEAN5 $_{i t}+$ $\beta_{13} A E C_{i t}+u_{1 i t}$

$A F D I_{i t}=\alpha_{2 i}+\delta_{1} A I T_{i t}+\delta_{2} D O O_{i t}+$ $\delta_{3} G D P_{i t-1}+\delta_{4} I U_{i t}+\delta_{5} R W_{i t}+$ $\delta_{6} I N F_{i t}+\delta_{7} E R_{i t}+\delta_{8} N A F D I_{i t}+$ $\delta_{9} C E P T 1_{i t}+\delta_{10} C E P T 2_{i t}+$ $\delta_{11}$ AJFT $_{i t}+\delta_{12}$ ASEAN5 $_{i t}+\delta_{13} A E C_{i t}+$ $u_{2 i t}$

Where:

AIT : log of ratio export from country $i$ to ASEAN+6 countries to export from country $i$ to other countries in the world

AFDI: the ratio of FDI inflow from ASEAN+6 to country $i$ to GDP of country $\mathrm{i}$

DOO: log of Degree of Openness 
GDP : log of Gross Domestic Product with 2010 as the base year (lagged)

IU $\quad: \log$ of the ratio of internet users to the total population of each ASEAN+6 country

RW : log of real wages obtained by dividing real GDP by the number of employees

INF : $\log$ of Consumer Price Index of country $i$ in a year

ER : log of the real exchange rate, obtained by multiplying the nominal exchange rate by us CPI and divided by domestic CPI

SAV : log of the ratio of national savings to GDP

NAFDI : the ratio of FDI inflow from non-ASEAN+6 to i country to the GDP of i country

CEPT1 : dummy variable of the enactment of CEPT (tariff = $0)$ in ASEAN6 countries in 2010, where 2001-2009 $=0$; 2010-2017=1 for ASEAN6 countries

CEPT2 : dummy variable of the enactment of CEPT (tariff=0) in CLMV countries in 2015, where 2001-2014=0; 20152017=1 for CLMV countries
AJFTA : dummy variable based on ASEAN-Japan Free Trade Agreement (AJFTA+1) from 2008 where 2001-2008=0; 2009-2017=1 for ASEAN countries and Japan.

ASEAN5: dummy variable based on AANZFTA, ACFTA, AKFTA, and AIFTA from January 2010, where 2001-2009=0; 2010-2017=1 for ASEAN+5

AEC : dummy variable based on AEC, where 2001-2015=0; 2016-2017=1 for ASEAN countries.

\section{Data and Estimation Process}

This study used secondary data for ASEAN+6 from 2001-2017. It was obtained from websites and reports issued by the World Bank, UN, ASEANstat, ABS, NBS CHINA, JETRO, RBI, KOSIS, and NZ STAT. To achieve the research objectives, the data were analyzed based on the estimation results of the research model.

This study used panel data with two variables (AIT and AFDI) that indicate causality. During the study, the problem was the simultaneous problem between AFDI and AIT as the two variables exist in both models. Therefore, the estimation was conducted to observe the error 
correlation between the two variables. When errors in correlation and causality are found, the estimation was conducted using the Seemingly Unrelated Regression (SURE) method. SURE solved Error correlation and the Granger Causality test addressed error causality. However, when there are no causality and endogeneity in the two variables, the data were estimated using the panel data regression method, which includes Pooled Least Square (PLS), Fixed Effect Method (FEM), and Random Effect Method (REM).

The best estimation method was decided with the Chow test, the LM test, and the Hausman test. The classic assumption test was performed to maintain the reliability of the model. When a classic assumption problem was found, it was addressed by Generalized Least Square (GLS) estimation.

\section{RESULTS AND DISCUSSION}

This study used panel data of 272 observations from ten ASEAN countries and six partner countries in 2001-2017. The causality test and an error correlation test have not shown causality and endogeneity relationship in AIT and AFDI variables. Therefore, the estimation was conducted using the panel data estimation method. The Chow test, LM test, and Hausman test showed that the Fixed Effect Model (FEM) is a better option to estimate both models. However, due to heteroscedastic and autocorrelation problems in FEM estimation, Generalized Least-Square (GLS) is considered the best option to estimate the model.

Table 1 shows that the estimation results showed that $A S E A N$ Intra-Trade (AIT) is affected positively and significantly by ASEAN FDI (AFDI), where an increase of AFDI by $1 \%$ will increase AIT by $0.009 \%$. In other words, the increase in AFDI has more impact on ASEAN+6 trade with non-ASEAN+6 countries. AIT also has a positive and significant effect on AFDI, where an increase in AIT by $1 \%$ will increase AFDI by $4.17 \%$, ceteris paribus. With the increase in FDI flows between ASEAN+6 countries and trade with nonASEAN+6 countries, ASEAN's goal to become part of the world supply chain can be achieved. It confirms the findings by Majeed \& Ahmad (2007) that the relationship between AFDI and AIT in ASEAN is complementary. 
Table 1 Estimation Result of Generalized Least Square

\begin{tabular}{|c|c|c|c|c|c|}
\hline \multirow[b]{2}{*}{ Independent } & \multicolumn{5}{|c|}{ Generalized Least Square (GLS) } \\
\hline & AlT & AFDI & Country & AIT & AFDI \\
\hline Variable & & & & (Cons.) & (Cons.) \\
\hline AFDI & $0.009^{* * *}$ & & Australia & Omitted & Omitted \\
\hline AIT & & $4.171^{* *}$ & Brunei Darussalam & $1.83^{* * *}$ & -0.15 \\
\hline DOO & $-0.097^{\star * *}$ & dropped & Cambodia & $2.58^{* * *}$ & -10.96 \\
\hline GDP (-1) & $0.366^{\star * *}$ & dropped & China & $-1.75^{\star * \star}$ & -5.33 \\
\hline IU & $0.119^{* * *}$ & $-1.47^{* * *}$ & India & $-0.86^{* * *}$ & -8.84 \\
\hline RW & $-0.446^{\star * *}$ & dropped & Indonesia & $3.29^{* * *}$ & -27.62 \\
\hline INF & $-0.698^{* * *}$ & $5.29^{* *}$ & Japan & $0.93^{* *}$ & $-17.61^{*}$ \\
\hline ER & $-0.470^{* * *}$ & dropped & Lao PDR & $5.05^{\star * \star}$ & -21.51 \\
\hline SAV & $0.286^{* * *}$ & & Malaysia & 0.24 & -1.34 \\
\hline NAFDI & & $0.081^{* * *}$ & Myanmar & $2.91^{* * *}$ & -18.84 \\
\hline CEPT1 & $-0.122^{* *}$ & $-4.252^{* * *}$ & New Zealand & $0.55^{\star * *}$ & -0.60 \\
\hline CEPT2 & 0.01 & $2.552^{\star *}$ & Philippines & $1.13^{* * *}$ & -8.44 \\
\hline AJFTA & $0.11^{* * *}$ & $-1.405^{\star *}$ & Singapore & $0.53^{* * *}$ & 0.49 \\
\hline ASEAN5 & $0.108^{* * *}$ & $3.03^{* * *}$ & South Korea & $2.32^{* * *}$ & -5.41 \\
\hline AEC & -0.049 & 0.326 & Thailand & $0.93^{* * *}$ & -7.99 \\
\hline CONS & $6.199^{\star \star \star}$ & $-69.741^{* * *}$ & Viet Nam & $3.49^{\star * \star}$ & -23.11 \\
\hline $\mathbf{N}$ & 272 & 272 & & & \\
\hline R-SQUARED & 0.9548 & 0.8962 & & & \\
\hline
\end{tabular}

Note: ${ }^{*} p<0.1,{ }^{* *} p<0.05,{ }^{* * *} p<0.01$

Other influencing factors for AIT are the degree of openness and lagged GDP. The more open the economy, the less the trade ratio with ASEAN+6 countries, which means that ASEAN+6 trade is carried out with non-ASEAN+6 countries instead. This information is more specific compared to the findings by Tran et al. (2019) that only mentioned the trade openness increased exports.
These findings also confirmed if regional economic comprehensive is discriminating against non-member countries and DOO is not. In contrast with the degree of openness, lagged GDP encourages intra-trade significantly. This finding confirms the assumption that production in the previous year can create trade inflow in the coming year, as stated by (Hsiao \& 
Hsiao, 2006). This result suggests that if a country can successfully produce more output, that will boost trade next year.

In this study, the ratio of internet users to the population is used as a communication infrastructure approach. The greater the ratio of internet users, the higher the intra-trade. As internet access expands market scope, it can stimulate exports (Lin, 2015; Majeed \& Ahmad, 2007). In contrast, the impact of the ratio of internet users to ASEAN FDI is negative. It is because internet access reduced the motive of multinational companies to open new branches or companies abroad. Investors try to prevent purchases' uncertainty based on the internalization motif, which might cause transaction costs and time lags (Moosa, 2002). With internet access, uncertainty can be prevented as it allows easier access to information.

This study also confirmed the finding of previous studies that the increase in real wages will negatively affect intra-trade. It confirms the classical model that trade (exports) can occur when it can produce goods cheaply based on real wages and prices (Appleyard \& Field, Jr, 2014). An increase in real wages will increase the price of goods, thereby affecting costs
(Sethi et al., 2003). For this reason, it is necessary to control wage and price levels for ASEAN+6 countries. According to some studies, inflation provided a significantly negative impact on ASEAN+6 intra-trade. It indicated that the increase in prices of goods would decrease demand for exports from other ASEAN+6 countries. This finding did not support the theory that exports will increase along with an increase in price (Dornbusch, Fischer, \& Startz, 2014).

Conversely, price levels positively affect AFDI, which means prices attract investors to invest their capital. Increasing prices in the short-run can boost producers to invest more capital (Ismail, 2009) and produce more. Increasing prices in the short run also can boost the Gross Domestic Product (GDP). For some ASEAN countries, the market size and the available infrastructure are the main factors to attract FDI (Xaypanya et al., 2015). Therefore, inflation can be a significant factor in attracting FDI, directly or indirectly.

Besides price, the exchange rate and domestic savings affect AIT. The results of this study indicate that the depreciation of the exchange rate will decrease ASEAN intra-trade. This 
finding confirms the theory, which remarked that the depreciation currency exchange rate could encourage exports due to the decrease in the relative prices of exported goods abroad-specifically, export from ASEAN+6 to non-ASEAN+6 countries. Savings significantly posed a positive impact on trade, according to (Majeed \& Ahmad (2007), in line with the theory of two gaps. The theory describes the investment-savings and export-import gap in developing countries. Considerable savings become the source of eliminating domestic inequality, eliminating external inequalities by increasing export growth.

The existence of FDI from nonASEAN+6 countries has also significantly provided a positive effect on ASEAN FDI. It confirms Masron (2013) that non-ASEAN FDI has become a consideration for ASEAN+6 investors to invest FDI. FDI inflow from non-ASEAN countries raises the expectations that the country's infrastructure, economic, and political conditions will support investment.

When the CEPT-FTA was implemented in 2010 in ASEAN6 countries, it negatively impacted on AFDI and AIT. This fact is inversely proportional to Ismail et al. (2009) argument that ASEAN FDI only revolves around the ASEAN5 countries. CEPT1 cannot boost FDI because of restrictions in a few sectors or because domestic absorption is not ready to imbibe new investment. In aggregate, this finding also shows if there is no trade creation after AFTA-CEPT1. Inversely with Okabe \& Urata's (2014) findings, trade creations occur on export and import products after AFTA. Following the enactment of CEPT-FTA (CEPT2) to all ASEAN countries in 2015, AFDI and AIT's flow had increased. Meanwhile, the impact of CEPT-FTA on intra-trade is insignificant. That indicates if the investment creation effect of CEPT-FTA in 2015 or the trade creation effect has moved to investment creation after CEPT-FTA was applied to all member countries.

Free Trade Agreement with ASEAN+ countries showed different impacts on ASEAN-FDI and ASEAN intra-trade. When the ASEAN-Japan Free Trade Agreement (AJFTA) is enacted, ASEAN-FDI flows declined by an average of $1.4 \%$ for Japan and ASEAN countries. It is assumed to be caused by investors who preferred to trade rather than investing. Unlike ASEAN FDI, the average of ASEAN Intra-Trade increased by $0.11 \%$ after the enactment of AJFTA. In comparison, the 
impact of cooperation with five other partner countries, such as China (ACFTA), South Korea (AKFTA), India (AIFTA), Australia, and New Zealand (AANZFTA), showed significant positive impacts on AFDI and AIT. In other words, AFTA+ can encourage AIT and $A F D I$, and ASEAN's goal to increase investment through AFTA+ can be achieved. These findings support the argument if ASEAN+3 is more effective in increasing trade and investment, which is in line with ASEAN's goal to build a production network in ASEAN (Magasházi, 2015).

The AEC's impact is positive on investment flows and negative on trade, but they are not significant. AEC strengthens investment flows between ASEAN countries. In other words, AEC is a step to bring ASEAN as a production base. Based on AFTA+ and AEC, investment in ASEAN keeps increasing rather than trade. It is another proof if ASEAN already moved on from trade creation to investment creation.

GLS estimation results showed that fourteen ASEAN+6 countries, except China and India, compete in trade to increase trade and investment potentials between the member countries. India decided not to join the RCEP by considering their infant industries would not be able to compete with goods from China. Based on AFDI estimation, fifteen ASEAN+6 countries except Singapore belong to the same group, and they might strengthen or compete.

\section{CONCLUSIONS AND POLICY RECOMMENDATIONS}

Some conclusions can be drawn from this study. First, ASEAN FDI and ASEAN intra-trade significantly have positive effects on each other even though AFDI does not push AIT as strong as the encouragement of AIT towards FDI. Thus, it indicates that trade does not occur between ASEAN+6 countries but with other countries. Then, the second phase of CEPT-AFTA boosts ASEAN FDI following the enactment of CEPT-AFTA for all ASEAN countries even though the second phase of CEPT-AFTA has not affected intra-trade significantly. ASEAN's on the road of investment creation also has proven with the findings that AEC pushes ASEAN FDI and ASEAN's trade with other nonmember countries. Therefore, it can be concluded that ASEAN is on the right track to achieve the goal of being part of the world's supply chain.

The ASEAN-Japan Free Trade Agreements (AJFTA) provided a 
significant negative impact on ASEANFDI and the significant positive one on intra-trade. This finding shows that ASEAN needs more partner countries to increase FDI. The impacts of ASEAN economic integration with five other partner countries (China (ACFTA), South Korea (AKFTA), India (AIFTA), Australia, and New Zealand (AANZFTA)) have succeeded increase ASEAN intra-trade and FDI after its enactment in 2010. To increase investment and trade, ASEAN and the six partner countries should form more comprehensive cooperation like RCEP. Therefore, ASEAN's decision to join RCEP is the right step.

Policy recommendations for ASEAN countries to increase intratrade ASEAN and ASEAN-FDI are Regional Comprehensive Economic Partnership (RCEP), opening investment opportunities for NonASEAN+6 countries, and increasing internet access. RCEP can increase the investment potential between members, therefore it is better not to postpone the RCEP signing plan in November 2020, and it should be made effective within one to two years following the signing of the agreement.

\section{ACKNOWLEDMENT}

The authors thank Fitrah Faisal, Ph.D. and Chaikal Nuryakin, Ph.D. for sharing their expertise and give us appropriate suggestions that made this article better.

\section{REFERENCE}

Appleyard, D. R., \& Field, Jr, A. J. (2014). International Economics (Eighth). Singapore: McGraw- Hill Education.

ASEAN. (2007) Piagam Perhimpunan Bangsa-Bangsa Asia Tenggara, Pub. L. No. 1 Ayat 5. ASEAN.

ASEAN. (2012). Agreement On The Common Effective Preferential Tariff (CEPT) Scheme For The ASEAN Free Trade Area Singapore, 28 January 1992. Retrieved September 28, 2019, from https://asean.org/?static post=agree ment-on-the-common-effectivepreferential-tariff-cept-scheme-forthe-asean-free-trade-area-singapore28-january-1992

ASEAN. (2019, November). Chairman's Statement Of The 35th Asean Summit Bangkok/Nonthaburi, 3 November 2019 Advancing Partnership For Sustainability. ASEAN, 1-17.

ASEANStats Data Portal. (2019). https://data.aseanstats.org/.

Aziz, O. G. (2018). Institutional quality and FDI inflows in Arab economies. Finance Research Letters, 25, 111123.

Bank Indonesia. (2008). MASYARAKAT EKONOMI ASEAN (MEA) 2015: Memperkuat Sinergi ASEAN di Tengah Kompetisi Global. Jakarta: PT Elex Media Komputindo.

Basri, F. (2010). Dasar-dasar Ekonomi Internasional: Pengenalan \& Aplikasi Metode Kuantitatif (1st ed.). Jakarta: Kencana.

Belloumi, M. (2014). The relationship 
between trade, FDI and economic growth in Tunisia: An application of the autoregressive distributed lag model. Economic Systems, 38(2), 269-287.

Cantah, G. W., Brafu-Insaidoo, G. W., Wiafe, E. A., \& Adams, A. (2018). FDI and Trade Policy Openness in SubSaharan Africa. Eastern Economic Journal, 44(1), 97-116.

Choi, C. (2003). Does the Internet stimulate inward foreign direct investment? Journal of Policy Modeling, 25(4), 319-326.

Dornbusch, R., Fischer, S., \& Startz, R. (2014). Macroeconomics (12th ed.). Singapore: McGraw-Hill.

Hadili, A., Raab, R., \& Wenzelburger, J. (2020). Trade liberalisation, governance, and the balance of payments: evidence from the Arab Maghreb Union. Middle East Development Journal, 8120.

Hattari, R., \& Rajan, R. S. (2009). Understanding bilateral FDI flows in developing Asia. Asian-Pacific Economic Literature, 23(2), 73-93.

Hoang, H. H., \& Goujon, M. (2018). Determinants of Intra-Region and Extra-Region Foreign Direct Investment Inflow in ASEAN: A Spatial Econometric Analysis. Applied Spatial Analysis and Policy.

Hsiao, F. S T, \& Hsiao, M. C. W. (2004). The chaotic attractor of foreign direct investment - Why China? A panel data analysis. Journal of Asian Economics, 15(4), 641-670.

Hsiao, Frank S. T., \& Hsiao, M.-C. W. (2006). FDI, exports, and GDP in East and Southeast Asia - Panel data versus time-series causality analyses. Journal of Asian Economics, 17, 1082-1106.

Ismail, N. W. (2009). The determinant of foreign direct investment in ASEAN: A semi-gravity approach. Transition Studies Review, 16(3), 710-722.
Ismail, N. W., Smith, P., \& Kugler, M. (2009). The Effect of ASEAN Economic Integration on Foreign Direct Investment. Journal of Economic Integration, 24(3), 385-407.

Jawaid, S. T., Raza, S. A., Mustafa, K., \& Karim, M. Z. A. (2016). Does Inward Foreign Direct Investment Lead Export Performance in Pakistan? Global Business Review, 17(6), 1296-1313.

Ju, J., Wu, Y., \& Zeng, L. (2010). The impact of trade liberalization on the trade balance in developing countries. IMF Staff Papers, 57(2), 427-449.

Li, Q., Scollay, R., \& Maani, S. (2016). Effects on China and ASEAN of the ASEAN-China FTA: The FDI perspective. Journal of Asian Economics, 44, 1-19.

Lin, F. (2015). Estimating the effect of the Internet on international trade. Journal of International Trade and Economic Development, 24(3), 409-428.

Magasházi, A. (2015). The integraton by trade and FDI of emerging economies: The ASEAN example. Society and Economy, 37(2), 207223.

Mahmoodi, M., \& Mahmoodi, E. (2016). Foreign direct investment, exports and economic growth: evidence from two panels of developing countries. Economic Research-Ekonomska Istraživanja, 29(1), 938-949.

Majeed, M. T., \& Ahmad, E. (2007). FDI and exports in developing countries: Theory and evidence. Pakistan Development Review, 46(4).

Masron, T. A. (2013). Promoting intraASEAN FDI: The role of AFTA and AIA. Economic Modelling, 31(1), 4348.

Masron, T. A., \& Nor, E. (2013). FDI in ASEAN-8: Does institutional quality matter? Applied Economics Letters, 20(2), 186-189.

Masron, T. A., \& Yusop, Z. (2012). The 
ASEAN investment area, other FDI initiatives, and intra-ASEAN foreign direct investment. Asian-Pacific Economic Literature, 26(2), 88-103.

Moosa, I. A. (2002). Foreign Direct Investment: Theory, evidence, and practice. New York: Palgrave.

Okabe, M., \& Urata, S. (2014). The impact of AFTA on intra-AFTA trade. Journal of Asian Economics, 35, 12-31.

Quazi, R. (2007). Economic freedom and foreign direct investment in East Asia. Journal of the Asia Pacific Economy, 12(3), 329-344.

Sethi, D., Guisinger, S. E., Phelan, S. E., \& Berg, D. M. (2003). Trends in Foreign Direct Investment Flows: A Theoretical and Empirical Analysis. Journal of International Business Studi, 34(4), 315-326.

Shahzad, A., Mithani, D. A., Al-Swidi, A. K., \& Fadzil, F. H. B. (2012). Political Stability and the Foreign Direct Investment Inflows in Pakistan. British Journal of Arts and Social Sciences, 9(II), 199-213.

Soekro, S. R. I. (2015). Working Paper Mapping And Determinants Of IntraAsean Foreign Direct Investment (FDI): Indonesia Case Study (WP/12/2015). Jakarta.

Thangavelu, S. M., \& Narjoko, D. (2014). Human capital, FTAs and foreign direct investment flows into ASEAN. Journal of Asian Economics, 35(8), 65-76.
Tran, N. Van, Alauddin, M., \& Tran, Q. Van. (2019). Labour quality and benefits reaped from global economic integration: An application of dynamic panel SGMM estimators. Economic Analysis and Policy, 63, 92-106.

Urata, S. (2018). Free Trade Agreements and Patterns of Trade in East Asia from the 1990s to 2010s. East Asian Community Review, 1(1-2), 61-73.

Verico, K. (2017). THE FUTURE OF THE ASEAN ECONOMIC. London: Palgrave Macmillan.

Verico, K., \& Natanael, Y. (2018). Let's talk about the Free Trade Agreement (FTA): The five ASEAN members highlighting Indonesia (No. 023). Jakarta.

Xaypanya, P., Rangkakulnuwat, P., \& Paweenawat, S. W. (2015). The determinants of foreign direct investment in ASEAN. International Journal of Social Economics, 42(3), 239-250.

Yang, S., \& Martinez-Zarzoso, I. (2014). A panel data analysis of trade creation and trade diversion effects: The case of ASEAN-China Free Trade Area. China Economic Review, 29, 138151.

Zghidi, N., Mohamed Sghaier, I., \& Abida, Z. (2016). Does Economic Freedom Enhance the Impact of Foreign Direct Investment on Economic Growth in North African Countries? A Panel Data Analysis. African Development Review, 28 (1), 64-74. 
